\title{
Land Use Influence on Water Pollution: the Research of Šalčia River Catchment
}

\author{
Andrius Litvinaitis, Lina Bagdžiūnaitè-Litvinaitienè, Elvyra Šinkovič \\ Department of Hydraulics Vilnius Gediminas Technical University, Sauletekio ave. 11, LT-10223 Vilnius, Lithuania.
}

\begin{abstract}
This paper examines Šalčia river water pollution, there were selected 24 water sampling points where was detected concentration of these nutrients: ammonium nitrogen, nitrate nitrogen, nitrite nitrogen, $\mathrm{pH}$, and total phosphorus. Samples were collected starting from the source of the river, to the mouth of the river, near the Merkys. Points selected according to the land use (catchment is dominated by forests $(52,7 \%)$ that have great economic value and nature protection, lower part of the catchment area takes arable land $(42,4 \%))$ and affluents so that the analysis of the results obtained during the experimental helped to determine factors leading to the maximum river water pollution. According to the data obtained there was found ecological status of the river.
\end{abstract}

Keywords: anthropogenic activities; nutrients; strength; field investigations; point pollution; diffuse pollution.

\section{Introduction}

Human performance studies show that unforeseen human impact on the environment is usually associated with a lack of understanding of the natural processes of integrity.

The economic performance analysis shows that the production of increased environmental and economic issues are becoming increasingly important in developed countries. Therefore, sustainable development - the growing needs of humanity while maintaining a healthy environment - is a strategic goal of many countries. This strategy will help to implement the scientific work carried out, with a strong focus on water pollution from agricultural sources to reduce [5].

Waters, especially rivers pollution depends on the run-off, and the nature of the mode is affected by factors such as climate, anthropogenic and natural geographical settings. Pauliukevičius [3] found that these factors lead to about $88 \%$ of the annual runoff in height, $85 \%$ of the maximum and the minimum $92 \%$ of the runoff change. The annual runoff most affected by climate factors, the maximum and minimum run-off the natural geographical and anthropogenic factors.

Small streams in different Lithuanian physical geographic areas, water quality depends on the natural conditions and the intensity of land use in the catchment [6]. The authors concluded that the highest nitrogen (N) concentrations in streams of Central Lithuania, where agriculture is the most intense and the river almost exclusively fed by surface water. They also found that the creek that feeds the surface and groundwater $\mathrm{N}$ load on the lower dilution cleaner groundwater.

Unlike diffuse pollution from point pollution can make it easier to identify and determine the adverse impacts on surface water bodies as point sources of pollution are generally of cities, towns or other objects larger discharges [4]. The researchers stressed that the economic performance of river catchments development and increasing the intensity of a significant impact on the regional economic situation, people's lifestyle and environment. A major concern is the negative impact of the activity of river water quality, and the greatest negative impact on river water quality makes the major cities, and expanding or renovating the water sector must first be taken into account these factors, the abolition of which will give the maximum effect.

\section{Materials and methods}

The study object is selected Šalčia River. River length $-75.8 \mathrm{~km}$, the catchment area is $748.9 \mathrm{~km}^{2}$ (Fig 1). Economic activity in catchment of Šalčia River is not intense - there are no major industries, farming complexes. One of the biggest

Corresponding author: Andrius Litvinaitis. E-mail address: andrius.litvinaitis@vgtu.1t

http://dx.doi.org/10.3846/enviro.2014.085

(C) 2014 The Authors. Published by VGTU Press. This is an open-access article distributed under the terms of the Creative Commons Attribution License, which permits unrestricted use, distribution, and reproduction in any medium, provided the original author and source are credited. 
polluters of the river water is JSC "Šalčininkų fishing farm", which has been operating since 1966. Farmed carp, pike, crucian carp, grass carp. The ponds are disinfected by quick lime each year. Pond water is not treated, the only bowl that reduces the suspended solids concentration. According to the Environment Agency data, the median Šalčia segment is of significant diffuse pollution effects and now in 1177 the river water due to diffuse pollution in good condition does not meet the criteria of 50 bodies of water, and it accounts for $5 \%$ of all water bodies.

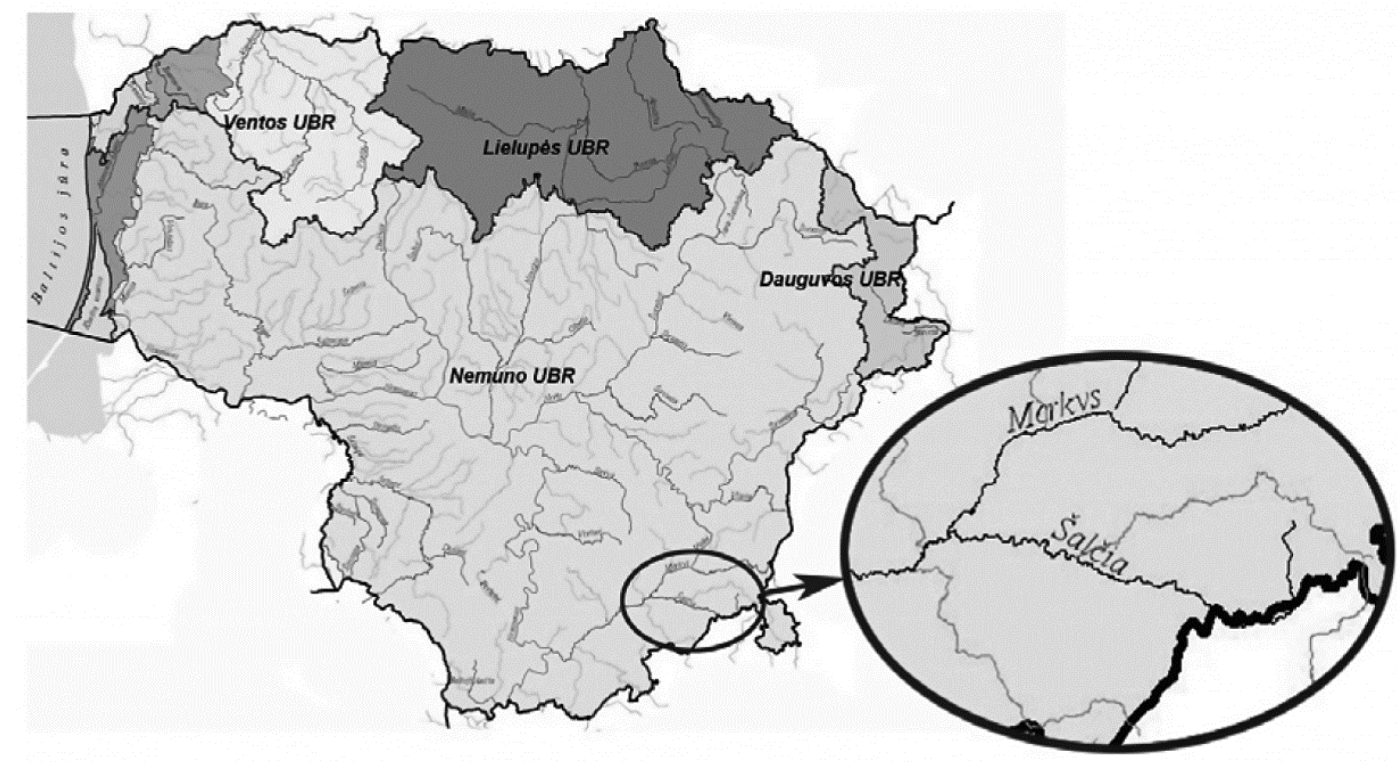

Fig. 1. Catchment of Šalčia River [7]

Land use impact assessment of Šalčia catchment is carried out by analyzing the collected data of period 2001-2010 of the Environmental Protection Agency and the Lithuanian Hydrometeorological Service, in kind research data of period of 2011-2012. 16 points in catchment of river Šalčia was selected for study from the source to the mouth of the river, according to the land use and tributaries.

\section{Results and discussion}

Land use distribution Šalčia river catchment area map using the National Land Authority vector database (LTDBK50000-V) was drawn (Fig 2). Point 4 below Šalčininkų town is surrounded by an area dominated by farmland, as well as the point closest to the source of the river Šalčia, compared with the other points. This point is also covered by water released from wastewater treatment plant and fishing ponds. This leads to increased anthropogenic activity by ammonium nitrogen concentrations than nitrite or nitrate nitrogen. Point 12 above Daržininkai is far from urban areas, on the one side of river dominated by forests, other - farmland, here we will find no ammonium nitrogen in the river water, but only nitrate nitrogen.

Research of nutrient showed that the ammonium nitrogen is predominantly in the river water in the middle of catchment (sampling point 10). Estuary (sampling point 16) studies showed that was dominated nitrate nitrogen. This kind of change in nitrogen affects land use in catchment area (Fig 3). 


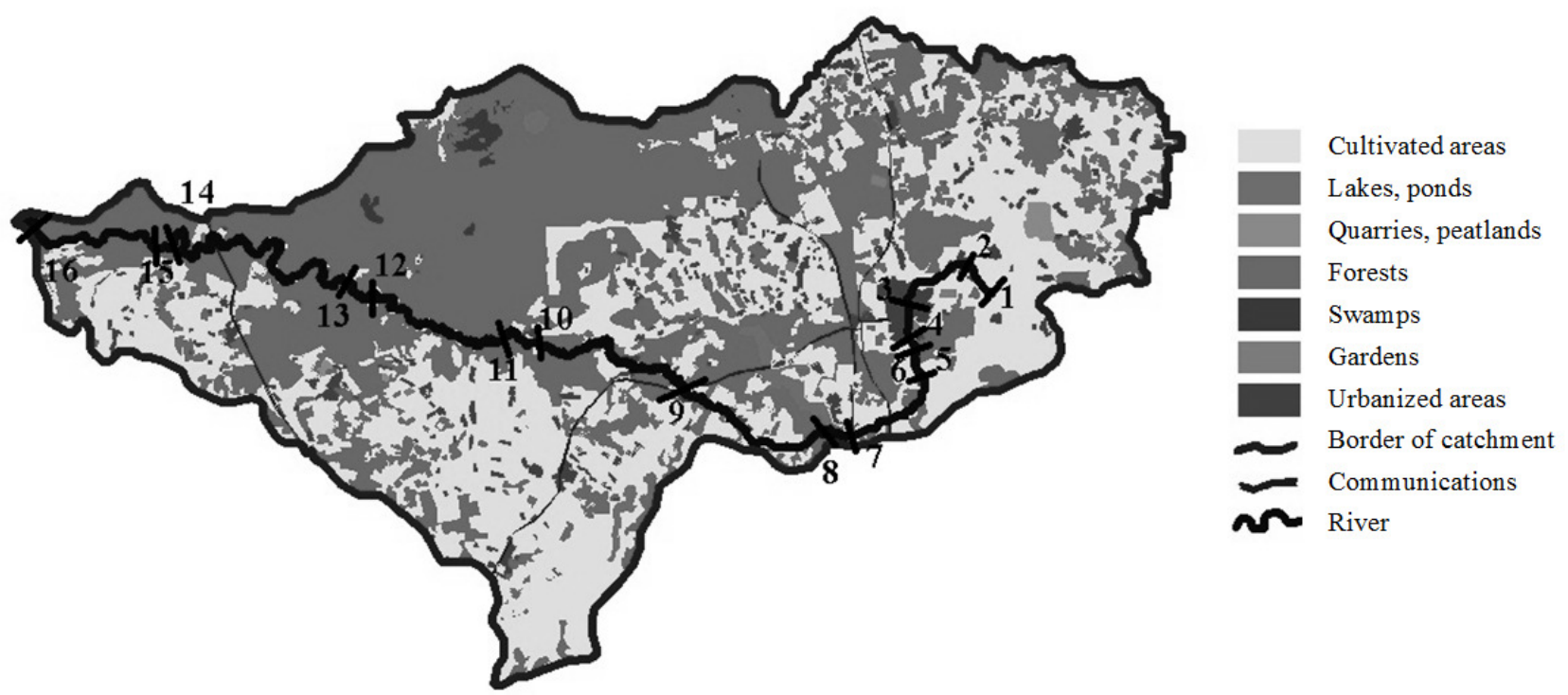

Fig. 2. Distribution of land use in catchment of Šalčia and sampling points

To assess the nutrient leaching should be monitored pollutant concentrations change along the river, which from the source to the mouth. Sampling locations are shown in Figure 2. These changes have created are shown in Figure 4. Points on the $\mathrm{x}$ axis indicate the schedule estimate water samples taken from the water (not take into account standing, pond or turbulent flow of water) quality. Analyzing the changes in the concentration of ammonium nitrogen in the river water seeing sharp increases in pollutant at 5,6 , and 8 points. Point 5 is just behind Šalčininkų wastewater treatment plant discharger, point 6 is located 1 kilometer from the discharger, point 8 is just behind JSC "Šalčininkų fishing farm". Therefore municipal wastewater treatment plants pollute more water than the river fish farm effluent. It has been established that the river purified from ammonium nitrogen by up to $66 \%$ within 1 kilometer.

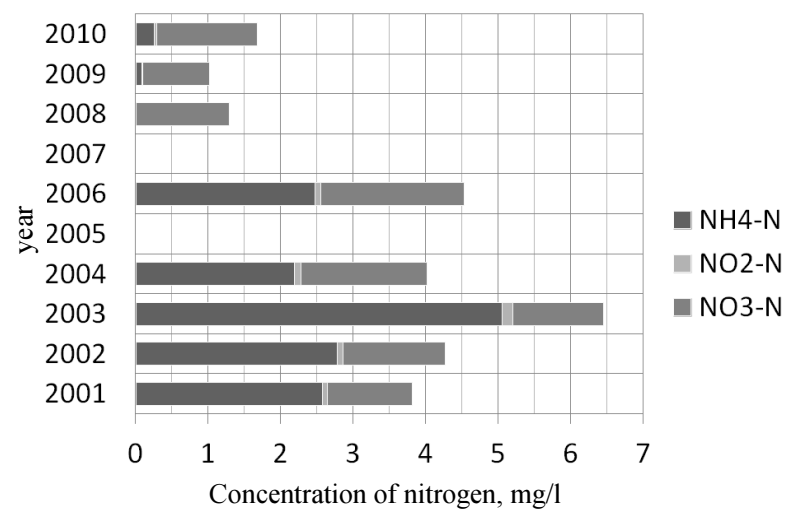

Fig. 3. Concentration of nitrogen in the Šalčia river water

Lowest annual average nitrate nitrogen concentration found in the upper reaches of the river - at the point 1 (1.09 mg/1), and the highest $(2.41 \mathrm{mg} / \mathrm{l})$ - just behind treatment plant discharger. Therefore anthropogenic point pollution have a higher negative impact on the quality of the river than the diffuse pollution from agricultural pollution assessment of nitrate nitrogen. Has been established that the river water purified from the nitrate nitrogen 5\% per 1 kilometer from the wastewater treatment plant discharger. While fishing ponds wastewater dilutes the river water so that the average annual nitrate nitrogen concentration in the river water was nearly halved (from $2.18 \mathrm{mg} / 1$ is reduced to $1.24 \mathrm{mg} / 1$ ).

It was established that tributaries of the river are affected differently by the pollution of this nutrients:

- tributary, which flows through the cultivated fields increases the nitrate nitrogen concentration;

- tributary that flows both cultivated and wooded area, although only slightly, but dilutes the river water below the confluence;

- tributary, which flows through the fields and close to the mouth - the forest, and is supplied by underground springs after the confluence of the predominantly of the other tributaries dilutes the water of river Šalčia.

Nitrite nitrogen concentration in river water is the smallest and the different factors which dischargers, tributaries, reacts similarly to nitrate nitrogen. The lowest concentration of a pollutant is in the point 1 and closer to the mouth - points 15 and 16. Domestic wastewater treatment plant river pollution nitrite nitrogen increases of $25 \%$ and within 1 kilometer river not purifies himself, pollutant concentration remains the same. Since nitrite nitrogen concentration is very low, it is not even a 
slight change in the large percentage of necessity, ie after fishing pond outlet concentration of the pollutant in the river Šalčia dropped $0.01 \mathrm{mg} / 1$, which corresponds to $34 \%$. Neither Šalčykščia tributary or tributary Visinčia not replace nitrite nitrogen pollution in the river, but the river tributary Brasta dilutes the water and reduces pollution by $50 \%$.

The concentrations of total phosphorus in the river water is similar to that of ammonium nitrogen, but its minimum value is the point 4, after the pond at Šalčininkų town. Therefore stagnant the pond water has the greatest impact on the average annual total phosphorus concentrations. The tributary Šalčykščia increases Šalčia river water to the pollution of total phosphorus by $16 \%$, but to the next tributary, river flows through the wooded area, and total phosphorus purified as much as $38 \%$. Visinčia also increases pollution, but only $5 \%$. Brasta tributary dilutes river water by $15 \%$ of total phosphorus. By the mouth of impaired even $17 \%$.
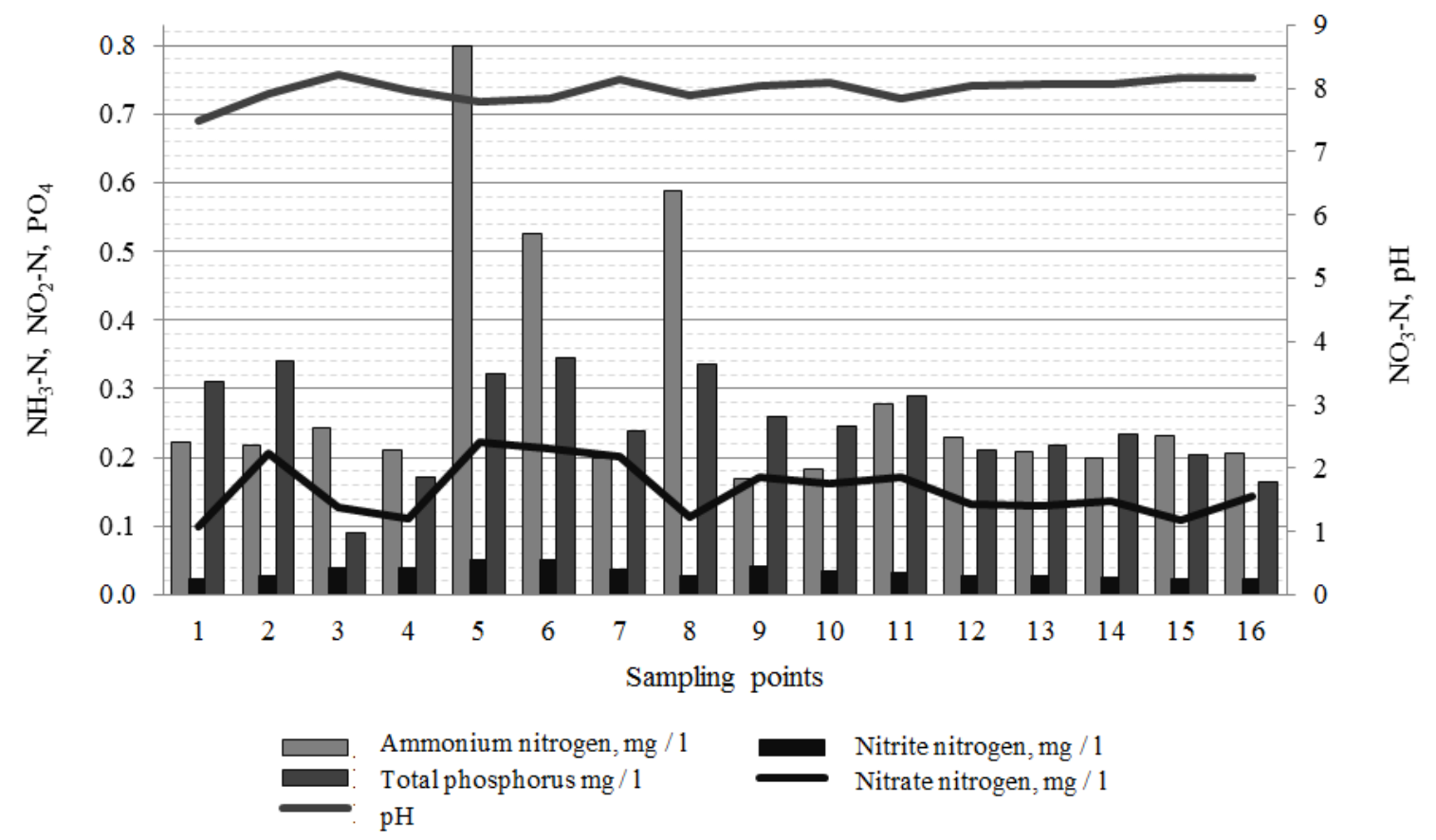

Fig. 4. Annual concentrations of nutrients in the river water

Such a distribution of nutrients leaching examines Pauliukevičius ir Berankienè [2]. They have chosen the experimental catchments and were setting leaching from different locations catchment or changing land use character in the river catchment. There was established a higher nutrient leaching in the upper reaches than in lower reaches. Scientists think that are better conditions to wash nutrients in the upper reaches of the river, and lower reaches - accumulate it. The examination of different research works any objection are made, such as the one the researchers conclusions are drawn that the agricultural area and wash of nitrogen and phosphorus content is a direct correlation [8]. Other scientists are doing the opposite conclusions - they argue that there is no correlation between the area of agricultural land and nutrient leaching [1]. Despite these contradictions, shows the general trend and pattern that agricultural intensification is an important part of increasing nutrient leaching reason.

\section{Conclusions}

The analysis of the distribution of land use showed that the larger urban areas, as close to the source, the higher the concentration of ammonium nitrogen in the water of the river, and close to the mouth and the prevail farmlands river water is contaminated with nitrate nitrogen.

The river and its tributaries situation directly affects water pollution - cultivated fields increases the concentrations of nutrients when the river flows both: the cultivated fields, and wooded areas concentrations of pollutants vary - one decreases, the other increases. When tributary flows half way through fields and forests, and then when it is supplied by underground springs, this stream in all cases reduces the emission concentration at the confluence.

Assessment of impact of the pond to the river water pollution by biogenic materials determined that the pond usually increases the $\mathrm{NH}_{3}-\mathrm{N}, \mathrm{NO}_{2}-\mathrm{N}$ concentration and an increase in alkalinity, and $\mathrm{NO}_{3}-\mathrm{N} \mathrm{PO}_{4}$ withdrawal. This distribution is in the river water under the pond. In the consumption of nutrients increases during the summer. 


\section{Acknowledgements}

We thank the Research Council of Lithuania for the opportunity to participate in program "Students research practice" and for funds for research.

\section{References}

[1] Gaigalis, K.; Šileika, A. S.; Šmitienè, A. 2006. Azoto ir fosforo koncentracijų kaita žemès ūkio veikiamuose upeliuose, Vandens ūkio inžinerija 30(50): 44-56. ISSN 1392-2335.

[2] Pauliukevičius, H; Berankienè, L. 2005. Žemės naudmenos kaip veiksniai, reguliuojantys Lietuvos upių užterštumą nitratų azotu, Vandens ūkio inžinerija 28(48): 38-44. ISSN 1392-2335.

[3] Pauliukevičius, H. 2007. Nuotėkị lemiančių veiksnių santykinė reikšmė ir regresijos lygčių taikymo galimybès, Vandens ūkio inžinerija 31(51): 58-65. ISSN 1392-2335.

[4] Radzevičius, A.; Dapkienè, M.; Česonienè, L. 2007. Sutelktosios aplinkos taršos mažinimas Ventos-Lielupės baseine, Vandens ūkio inžinerija 32(52): 42-47. ISSN 1392-2335.

[5] Šileika, A. S.; Gaigalis, K.; Šmitienè, A. 2005. Azoto ir fosforo junginių nuotèkio poveikis upių užterštumui, Vandens ūkio inžinerija 28(1): 75-85. ISSN 1392-2335

[6] Šileika, A. S.; Gaigalis, K. 2007. Gamtiniụ ir antropogeniniu veiksniu ịtaka azoto išplovai upeliụ baseinuose, Vandens ūkio inžinerija 31(51): 36-46. ISSN 1392-2335.

[7] Upių baseinu rajonai, Aplinkos apsaugos agentūra. Viewed 2013-01-03. http://vanduo.gamta.lt/cms/index

[8] Wayland, K. G.; Long, D. T.; Hyndman, D. W.; Pijanowski, B. C.; Woodhams, S. M.; Haack, S. K. 2003. Identifying Relationships between Baseflow Geochemistry and Land Use with Synoptic Sampling and R-Mode Factor Analysis, J. of Environ. Qual. 32: 180-190. ISSN 0047-2425. 